\title{
El Nazareno de León y la obra de Gregorio Fer- nández
}

\author{
César García Álvarez \\ Eduardo Álvarez AlLER \\ Universidad de León
}

Artículo recibido: 30-4-2012 / Aceptado: 8-6-2012

Resumen: La imagen titular de la leonesa Cofradía del Dulce Nombre de Jesús Nazareno ha sido considerada tradicionalmente como una talla de escaso valor, y anónima o atribuida a escultores de segunda fila. Por el contrario, el análisis exhaustivo de sus formas revela un grado de similitud tan asombrosamente exacto con respecto a las obras efectuadas por Gregorio Fernández durante los últimos años de la década de 1610, que permite atribuir al genial escultor barroco, con total seguridad, la ejecución de la cabeza y las manos de la citada talla. Por otra parte, la nueva documentación que se aporta revela que la cofradía leonesa no sólo pudo tener vínculos con Gregorio Fernández, sino que estaba en condiciones económicas de encargar, en los años de su fundación y puesta en marcha, la imagen de su advocación al mejor escultor del momento.

Palabras clave: Jesús Nazareno, Escultura barroca hispana, Gregorio Fernández, Cofradía del Dulce Nombre de Jesús Nazareno.

Aвstract: The titular image of the leonese Cofradía del Dulce Nombre de Jesús Nazareno has been traditionally considered as a poor valued carving. However, the exhaustive analyze of its forms reveals such an amazing grade of similitude between it and the works created by Gregorio Fernández during the last years of the 1610 decade, that allows to attribute to the genial baroque sculptor, without a doubt, the execution of the head and hands of the aforementioned sculpture. On the other hand, the new documentation supplied reveals that not only the Cofradía could have had bonds with Gregorio Fernández, but that it was in economical conditions to entrust, in the years of its foundation, the image of its title to the best sculptor of the moment.

Key words: Nazarene (Christ bearing the Cross), Spanish baroque sculpture, Gregorio Fernández, Cofradía del Dulce Nombre de Jesús Nazareno.

La autoría de la imagen titular de la Cofradía del Dulce Nombre de Jesús Nazareno, de León, ha constituido un problema que no ha podido ser resuelto correctamente por los diferentes estudiosos que se han ocupado de ella. No debe resultar extraño, puesto que cualquier proceso de atribución de una autoría a una obra de arte suele ser particularmente complejo y encerrar grandes dificultades. Además, el conocimiento 
de la imagen de Nuestro Padre Jesús Nazareno no sólo está lastrado por graves carencias documentales, sino que tampoco ha sido objeto de los estudios técnicos que merecería, y que permitirían aclarar numerosos aspectos de la misma. Por ello, la única posibilidad que existe para determinar la identidad de su artífice es realizar un análisis detenido y minucioso de sus características formales, a partir del cual proponer una atribución correcta y, lo que resulta tanto o más importante, descartar las atribuciones erróneas formuladas en diversas ocasiones. Antes de analizar la talla, sin embargo, es preciso abordar, aunque sea brevemente, el desarrollo histórico de las diferentes hipótesis sobre su creador.

La primera mención publicada que existe sobre la imagen aparece en 1925, en una obra de Raimundo Rodríguez, quien, al describir la capilla de Santa Nonia, apunta que en ella se encuentran "obras artísticas no despreciables [...], como el Nazareno"1. Tres años después, una de las primeras fotografías publicadas del Nazareno ofrece un detalle del rostro sin la peculiar peluca que entonces portaba ${ }^{2}$, lo que viene a confirmar que esta imagen contaba con la cabellera totalmente tallada (Figura 1). Ello permite confirmar la falsedad de una opinión popular, e incluso publicada en algunas ocasiones, según la cual la cabellera del Nazareno habría sido creada por Víctor de los Ríos. Lo refuta también el hecho de que el Nazareno salió algún año en procesión sin la peluca, tal como demuestra una fotografía de Manuel Martín de la Madrid correspondiente a 1939, varios años antes de la intervención de Víctor de los Ríos ${ }^{3}$.

\footnotetext{
${ }^{1}$ R. RODRÍGUEZ, y W. TESTERA, Guía artística de León, León, 1925, pp. 138-139.

${ }^{2}$ Semana Santa. León, 1928, p. 3.

${ }^{3}$ El Nazareno delante de la antigua cárcel. Fotografía de Manuel Martín de la Madrid. 1939, en Historia de una cofradía. La procesión de los Pasos en la primera mitad del siglo XX. Fotos de Manuel Martín de la Madrid, León, 2011.
}

Hacia mediados del siglo XX aparecen publicadas diferentes reseñas que, por lo general, se limitan a describir la talla como anónima. Sin embargo, en alguna de ellas se niega de modo esquemático la autoría de Gregorio Fernández ${ }^{4}$, mientras que otros autores atribuyen la autoría al escultor de Sarria ${ }^{5}$. Surge asimismo una leyenda, sin fundamento histórico, que ve en un hijo del imaginero gallego al autor de la obra, la cual, tras su prematuro fallecimiento, sería finalizada por el propio Fernández $z^{6}$.

Entre diciembre de 1943 y enero de 1944, Víctor de los Ríos, tras formular un ofrecimiento a la Cofradía, realizó de forma altruista un cuerpo para la cabeza del Nazareno ${ }^{7}$. Para tal empresa la imagen del Nazareno fue trasladada al taller madrileño del escultor. Al concluir el trabajo la imagen se expuso en Madrid, hecho que permitió difundir la efigie entre la sociedad madrileña y publicar fotografías en la prensa ${ }^{8}$. El citado imaginero también talló los pies. La cabeza no sufrió transformación alguna, tal como atestiguan los testimonios gráficos ${ }^{9} \mathrm{y}$

\footnotetext{
4 "No parece suyo, ni éste tenía cuando esta imagen fue esculpida la fama y nombre que después adquirió", en "El Nazareno", Diario de León, 19-4-1946, p. 1.

5 "De la referida Cofradía queda el magnífico Nazareno, algún tiempo atribuido a Carmona, pero que modernamente se cree sea debido al cincel de Gregorio Hernández o Fernández, [...] y por el contrario el dramatismo del Nazareno mejor responde a las características de Hernández", "El arte en nuestras procesiones", Arte. Revista Leonesa. Extraordinario de Semana Santa, 1950.

${ }^{6}$ S. DE PAZ, "El Nazareno de Gregorio Fernández", Semana Santa leonesa, León, 1951, pp. 32-33 y Pregón de la Semana Santa Leonesa 1954, León, 1954.

${ }^{7}$ Archivo de la Cofradía del Dulce Nombre de Jesús Nazareno (en adelante ACJN). Libro de Actas. 19391967. Junta de Seises 8-12-1943 y 20-1-1944.

${ }^{8}$ E. ÁLVAREZ ALLER, "Víctor de los Ríos y la difusión de la Semana Santa de León en Madrid", Pasión. Semana Santa de León 2012, pp. 64-66.

${ }^{9}$ C. ALONSO GÓMEZ, León (España) Manual del turista, Valladolid, 1953, p. 143 y Foto Exakta - León, ca. 1946, entre otros.
} 
la prensa del momento ${ }^{10}$. Sin embargo, el Nazareno siguió saliendo ocasionalmente en procesión con peluca, de la cual no se prescindiría definitivamente hasta $1952^{11}$.

Dada la carcoma detectada en la cabeza del Nazareno, en 1960 la Cofradía confió a Isaac Martín Granizo la conservación de la misma, de acuerdo con las normas proporcionadas por el Museo de Valladolid ${ }^{12}$.

En 1980, José María Villanueva Lázaro atribuye el Nazareno a Pedro de la Cuadra, pero de un modo esquemático, sumario, y, como suele, por desgracia, ser muy frecuente en su obra, sin citar las fuentes de las cuales obtiene su información. Afirma que es "obra del primer tercio del siglo XVII, de escuela vallisoletana, obra de Pedro de la Cuadra, imagen hecha para vestir, por lo que sólo tenía cabeza, manos y pies, hasta que modernamente se la completó con el cuerpo;"13. Villanueva refleja también otra idea tradicionalmente aceptada, pero que, a la luz de los testimonios documentales que conocemos, resulta altamente improbable, como lo es la consideración del Nazareno como una imagen de vestir, y mucho menos de bastidor ${ }^{14}$.

Máximo Cayón Waldaliso será el primero que de forma argumentada estudie las diferentes atribuciones vertidas acerca de la efigie que estamos analizando, rechazando la intervención de Juan de Juni y de Luis Salvador Carmona, e inclinándose por Gregorio Fernández como su autor. Afirma literalmente: "De todas formas, de un modo u otro, no es nada venturado decir que el Nazareno

${ }^{10}$ Proa, 26-3-1944, p. 5 y Diario de León, 27-3-1944, p. 4.

${ }^{11}$ ACJN. Libro de Actas. 1939-1967. Junta de Seises 9-3-1952.

${ }^{12}$ ACJN. Libro de Actas. 1939-1967. Junta de Seises 21-10-1960.

${ }^{13}$ J. M. VILLANUEVA LÁZARO, La ciudad de León. Del gótico-mudéjar a nuestros días. Siglos XIV-XX, León, 1980, p. 184.

${ }^{14}$ Cfr. infra. El encargo que se efectúa a Díez de Tudanca para ahuecar la imagen del Nazareno prueba que esta era maciza. de esta cofradía es de la escuela de Gregorio Fernández. No faltan indicios para ello, puesto que tiene rasgos y detalles que encajan plenamente con la época del ilustre pontevedrés y con la primera etapa, digamos, del Dulce Nombre de Jesús Nazareno" 15 .

En 1983, José Javier Rivera Blanco emite un informe ${ }^{16}$ en el que concluye que "no se debe ni a Gregorio Fernández ni a Pedro de la Cuadra, entre otros, y contextualiza la pieza en el hacer de un taller vallisoletano entre 1640 y 1650. Afirma que "estudiada la cabeza científicamente -único y parcial resto original que se conserva- la obra no corresponde ni a Juan de Juni, ni a Gregorio Fernández, ni a Luis Salvador Carmona ni a Pedro de la Cuadra. Imposible de Juni, imaginero francés afincado en España que falleció en 1577 (la imagen del Nazareno sería posterior a 1611). Menos aún de Carmona, activo en el siglo XVIII. Técnica y estilísticamente tampoco de Gregorio Fernández (falleció en 1637) por escasa calidad, deficiencias en la utilización de la gubia y otros pormenores, todos ellos cualitativa y cuantitativamente suficientes como para demostrar tal aserto. Por otra parte, es muy difícil que pertenezca a Pedro de la Cuadra, con quien mantiene algunos rasgos, pero se separa en muchos otros" Rivera concluye que "se trata de una obra de escuela Castellana, imitadora de las formas de Gregorio Fernández, realizada probablemente entre 1640 y 1650 en un taller de Valladolid, entonces principal centro de imaginería de la mitad Norte de la Península Ibérica. En el año 1814, tras el incendio, fue trasladada la imagen junto con los restos salvados del mismo a la capilla de Santa Nonia ${ }^{17}$. Dos años después, se compusie-

15 M. CAYÓN WALDALISO, Cofradía del Dulce Nombre de Jesús Nazareno. León, 1982, pp. 182-183.

${ }^{16}$ ACJN. Libro de Actas Juntas 1981 a 1984, Junta de Seises 20-1-1984, f. 81.

${ }^{17}$ A día de hoy no hay constancia documental de los efectos producidos por el supuesto incendio y ni siquiera si éste afectó al patrimonio artístico de la iglesia conventual de Santo Domingo, puesto que una parte considerable se encuentra diseminada por diferentes templos de la ciudad de León, como la Virgen del Rosario de Juan de Juni, en Santa Marina la Real, o las diversas imágenes que del siglo XVI y XVII conservan 
ron los pasos y entre ellos el Nazareno. Apenas se había podido salvar la cabeza -entonces con cabellos naturales-"18.

En 1984, el escultor Luis Estrada efectúa una intervención sobre el Nazareno ${ }^{19}$, la cual consistió en "una limpieza total de cabeza y rostro, tratándole de carcoma, y efectuando los arreglos que fueron necesarios. Por lo que se refiere al cuerpo, se le han dado formas en caderas, glúteos y muslos, de lo que carecía. Le han ampliado los hombros, procediéndose al arreglo de los brazos, pies y base de la efigie." ${ }^{20}$

Para el historiador del arte Fernando Llamazares, "la paternidad de los dos pasos de Grajal como obras de Pedro de la Cuadra, nos lleva a la conclusión de la adjudicación al mismo del Nazareno de la Cofradía de Jesús de la iglesia de Santa Nonia de León, pues su estilo coincide plenamente, si bien es modelo más emotivo" ${ }^{21}$. Será desde este momento cuando adquiera pujanza esta atribución y se vea a Pedro de la Cuadra como autor de la cabeza del Nazareno, atribución inexplicablemente no discutida durante veinte años ${ }^{22}$ (Figura 2).

La falta de rigor de la mayor parte de las atribuciones y afirmaciones de toda índole vertidas sobre la imagen del Nazareno ha conducido a consolidar fuertes prejuicios sobre su propia calidad artística, la cual ha sido, como veremos, injustamente infravalorada. Así, es posible encontrar afirmaciones tales como que "no es una obra excepcio-

las Cofradías de Nuestra Señora de las Angustias y Soledad y del Dulce Nombre de Jesús Nazareno en Santa Nonia, entre otros ejemplos.

18 "Paso de Jesús Nazareno", en Revista de la Cofradía del Dulce Nombre de Jesús Nazareno. León: Cofradía del Dulce Nombre de Jesús Nazareno, 1991.

${ }^{19}$ ACJN. Op. cit. Junta de Seises 22-6-1984, f. 97 r.

${ }^{20}$ Ibídem, Junta de Seises 7-9-1984, f. 99 v.

${ }^{21}$ F. LLAMAZARES RODRÍGUEZ, "Escultura barroca en León", en Historia del Arte en León, León, 1990, p. 247.

${ }^{22}$ El propio Llamazares Rodríguez afirmará sin rodeos que "es obra de Pedro de la Cuadra" en su Guía de León, León, 1992, p. 114-115. nal, pero su valor estriba en la gran devoción que muestra por ella el pueblo leonés" 23 .

Igual falta de fundamentación se aprecia en lo relativo a la cronología de la obra. Así, Javier Rivera la fecha, genéricamente, entre 1640 y 1650. Fernando Llamazares se inclina por situar el Nazareno en $1611^{24}$, mientras que Javier Caballero Chica sigue al anterior en la atribución pero difiere en el año de ejecución: "es atribuido a Pedro de la Cuadra, que lo realizó en 1612"25.

En 2008, Carlos García Rioja y Gonzalo F. González Cayón, en una comunicación presentada en el congreso Gregorio Fernández: vida, arte y cultura, celebrado en Valladolid, ya apuntaron sucintamente la similitud entre el Nazareno y el Cristo Atado a la Columna de la Vera Cruz de Valladolid. "Sin embargo, es de destacar el extraordinario paralelismo que esta imagen guarda con la de Jesús Atado a la Columna, firmada por Gregorio Fernández hacia 1619"26.

Finalmente, uno de los que suscribe rechazaba, ese mismo año, la atribución del Nazareno a Pedro de la Cuadra, con las siguientes palabras: "Aunque el Nazareno de Santa Nonia no sea obra directa de Gregorio Fernández, a la hora de realizar una atribución hay que fijar la vista en su taller, ya que las características formales responden a las de este escultor. Como decimos son muchas las similitudes con el Cristo atado a la columna de Valladolid, así como con otros Cristos que se pueden ver en la citada ciudad castellana. Boca entreabierta, efectista mirada al cielo, melena despejada en uno de sus lados que permite ver una oreja...etc. Esto nos

\footnotetext{
${ }^{23}$ G. MÁRQUEZ GARCÍA, “Historia y arte en los pasos", Semana Santa 2001, León, 2001, p. 67.

${ }^{24}$ F. LLAMAZARES RODRÍGUEZ, "La escultura procesional en León", Semana Santa de León, León, 2000, p. 101.

${ }^{25}$ J. CABALLERO CHICA, Las Cofradías, León, 2002, p. 27.

${ }^{26}$ C. GARCÍA RIOJA, y G. F. GONZÁLEZ CAYÓN, "Gregorio Fernández y su impronta en la imaginería procesional leonesa", Gregorio Fernández: Antropología, historia y estética en el barroco, Valladolid, 2008, p. 487.
} 
lleva a pensar que el Nazareno sea obra de algún artista muy próximo a Gregorio Fernández, tanto en el espacio como en el tiempo, algún oficial o discípulo de su taller, puesto que los posteriores artistas que son considerados seguidores del maestro gallego nunca alcanzaron su destreza compositiva. Como ejemplo puede servir el Expolio, talla de Francisco Díez de Tudanca, seguidor de Fernández pero que artísticamente es inferior a su obra, con una gubia más torpe (...) habría que descartar a Pedro de la Cuadra como autor del Nazareno. Es incomprensible que de la Cuadra hubiera tallado esta imagen y después realice, en 1623, una imagen de Jesús Nazareno y un Cristo flagelado para Grajal de Campos que, artísticamente son inferiores" 27.

El presente estudio aspira a demostrar que no sólo esta última vía interpretativa es la correcta, sino que existen argumentos sumamente sólidos para atribuir directamente la autoría de la talla a Gregorio Fernández, los cuales permitirán rebatir las vaguedades, arbitrariedades e imprecisiones que pueblan la historiografía de esta pieza, y que pueden ser evitadas mediante un detenido análisis formal y estilístico que lo relacione con la producción escultórica del barroco hispano.

El punto de partida para ello pasa necesariamente por efectuar una comparación entre la imagen del Nazareno con aquella que ha servido de base y fundamento para la única atribución concreta propuesta hasta la fecha. Se trata de una escultura de Jesús Nazareno conservada en la iglesia de Grajal de Campos. El autor de esta imagen fue Pedro de la Cuadra, quien ante el comitente de las obras y vecino de Grajal de Campos, Juan de Tamargo, se obligó en 1623 “de acer... una figura de Cristo a la columna, otra figura asi mismo de Cristo con la cruz a cuestas... yten se declarar que el Cristo con la cruz a cuestas a de ser para vestir con la tunica, y asi ha de ir perfecionado caveza y cuello y brazos la mitad y las manos y los pies con un poco de las

${ }^{27}$ E. ÁLVAREZ ALLER, “Sobre la autoría de Nuestro Padre Jesús Nazareno", Revista de la Cofradía del Dulce Nombre de Jesús Nazareno, León, 2008, p. 29. piernas... se ha de encarnar de una encarnación mate muy limpia y muy bien hecha"28. Fernando Llamazares consideró que sus características formales la convertían en una prueba que permitía atribuir a dicho escultor la autoría de la imagen leonesa ${ }^{29}$ (Figuras 2 y 5).

Creemos que las imágenes son suficientemente elocuentes. Las diferencias de calidad entre ambas esculturas son, simplemente, abismales. La talla de Grajal de Campos exhibe limitaciones técnicas y tosquedad en todos los parámetros técnicos y estilísticos que pueden ser empleados para analizar una escultura barroca. Los defectos comienzan en el planteamiento volumétrico y proporcional. La cabeza presenta una manifiesta incompetencia en las relaciones mutuas entre sus partes, que constituyen el fundamento de la concepción clásica de la belleza, caracterizada por la relación armoniosa de las partes con el todo. La longitud del rostro es desproporcionada en relación con la anchura, y el juego de volúmenes entre la frente, los ojos, los pómulos, la nariz y la boca es igualmente desequilibrado. El tallado y la definición de todas las partes son técnicamente muy defectuosos. Todos los músculos faciales están realizados de modo esquemático y con escaso rigor anatómico, particularmente la zona orbicular, encerrada en una profunda oquedad que brinda a la imagen un carácter informe. Los pómulos están mal ubicados, y el conjunto resulta totalmente tosco y deforme.

Por su parte, las cejas son planas y describen una línea incoherente y rígida con relación a los ojos, a los que confieren una expresión mostrenca. El arco que conforman es exagerado y su simetría es rígida, mecánica y forzada. Los ojos, de madera y no de cristal, son igualmente débiles, enmarcados por un contorno rígido toscamente tallado. Las bolsas de los ojos están muy abultadas, la mirada es bizca y está enfocada hacia aba-

${ }^{28}$ F. LLAMAZARES RODRÍGUEZ, “Testimonio de siglos", en Semana Santa en León, León, 1995, p. 95.

${ }^{29}$ Véase supra, nota 21 
jo. La boca tampoco sale mejor parada: el labio superior está prácticamente sin tallar, y los dientes están mal esculpidos, además de resultar pequeños y estar separados. Por lo que respecta al cabello, se aprecia el esfuerzo del autor por dotarle de volumen y relativa independencia con respecto a la cabeza, pero el resultado es particularmente deficiente, como se puede apreciar en la disposición rígida de los mechones, y particularmente de la parte derecha de la cabellera, que se despliega en una secuencia paralela de mechones burdamente ondulada. Por otra parte, la policromía es de escasa calidad, y la superficie de la piel resulta basta, en contra, precisamente, de lo estipulado en el contrato.

Las diferencias de calidad entre ambas imágenes son tan intensas, que resulta absolutamente inaceptable afirmar que fueron creadas por un mismo escultor. Por el contrario, lo que revela la imagen de Grajal de Campos es el resultado de un evidente intento de imitar la perfección formal alcanzada por Gregorio Fernández. En este sentido, no debe olvidarse que la formación técnica y estética de Pedro de la Cuadra se enmarcó en unos parámetros propios de la sensibilidad clásica y romanista, y que el éxito de Fernández fue el desencadenante de un afán mimético emprendido por aquellos escultores que comenzaron a ver preteridas sus realizaciones por la extraordinaria acogida que los logros del escultor gallego encontraba por parte de los clientes. El triunfo del "naturalismo" fue el detonante de forzados cambios estilísticos por parte de escultores como De la Cuadra, quienes se esforzaron en vano para igualar los resultados que estaban propiciando a Fernández numerosos encargos y un prestigio extraordinario y creciente. Si ambas tallas poseen rasgos en común, ello se debe sin duda a que los modelos creados por Fernández, particularmente a partir de 1615 , como luego expondremos, se convirtieron en referencia obligada y desafío permanente para los escultores coetáneos. Cabe añadir, tal como explica Martín González, que Pedro de la
Cuadra "estuvo especializado en la escultura funeraria, y precisamente el auge que adquiere es un testimonio indirecto de que Fernández no se aplicó a este género, ya que entonces hubiera recibido encargos que fueron a manos de Pedro de la Cuadra"30.

Por el contrario, dentro del conjunto de la producción escultórica hispana del siglo XVII, la cabeza del Nazareno leonés resulta absolutamente similar, en un grado que sólo cabe calificar como asombroso, respecto a dos de las imágenes creadas por Gregorio Fernández, y que se conservan en la iglesia de la Vera Cruz de Valladolid. Nos referimos, por una parte, al Cristo coronado de espinas (ocasionalmente identificado como un Ecce Homo) (Figura 3), y, sobre todo, al Cristo atado a la columna, una de las imágenes nacidas de la gubia del escultor gallego, y considerada unánimemente como una de sus obras maestras (Figura 4).

Como muestran las imágenes, la cabeza del Cristo atado a la columna puede considerarse prácticamente un clon de la cabeza de Nuestro Padre Jesús Nazareno (Figuras 4 y 5). Las mínimas diferencias que las separan sirven únicamente como prueba de que una no fue copiada a partir de la otra mediante algún procedimiento mecánico como el sacado de puntos, y suponen también una muestra, como después expondremos, del proceder ocasional de Gregorio Fernández, quien elaboró pares o series de imágenes extremadamente similares entre sí de un modo cronológicamente simultáneo.

Las diferencias siempre resultan más fáciles de definir y expresar que las similitudes, por lo que es muy complicado exponer con variado vocabulario la repetición de identidades e igualdades que existen entre estas dos imágenes. Comencemos comprobando cómo las proporciones de ambas cabezas son idénticas. Todos los parámetros proporcionales son exactos en ambas: la lon-

${ }^{30}$ J. J. MARTÍN GONZÁLEZ, "Influencia”, en El escultor Gregorio Fernández, Madrid, 1980, p. 79. 
gitud y anchura del rostro, la distancia entre los ojos y entre estos y la boca, la forma de los pómulos, la suave curvatura que une y separa éstos del bigote, el ligero rehundido entre el pómulo y la barba, la ligera pero sumamente expresiva curvatura de las cejas, la forma de la nariz, (cuyas fosas nasales, por cierto, han sido dotadas, en un alarde más de rigor anatómico, de una profundidad extrema, lo que sólo se puede advertir mediante una inspección ocular directa como la que hemos efectuado), el contorno y la forma de los ojos, su carácter cristalino y su mirada ligeramente marcada hacia lo alto; el tallado del pelo, con idéntica melena que, en el lado izquierdo, muestra la oreja, son todos ellos rasgos absolutamente idénticos en ambas tallas, hasta en los más mínimos detalles. Las semejanzas entre las bocas y las barbas son tan estrechas, que costaría distinguir cuáles pertenecen a la talla correcta si se mostrasen separadas del conjunto del rostro. La apertura de la boca, la forma y el tallado de los dientes, tanto inferiores como superiores, son igualmente idénticos, así como la lengua, que no sólo es igual que la del Cristo Atado a la columna, sino que está tallada hasta la garganta, de un modo que sólo puede percibir un observador que se acerque hasta unos centímetros y dirija su mirada hacia el interior de la boca. Ello revela una exquisita atención a detalles anatómicos que pasarían desapercibidos para un espectador lejano o indiferente, cualidad que sólo está presente, con un grado tan acentuado de dominio técnico y rigor anatómico como el que se muestra en el Nazareno, en las mejores obras creadas por Fernández.

Por su parte, el pelo es extremadamente similar, tanto en la forma general como en sus detalles más precisos. Por el lado derecho del rostro, se divide entre una cascada ondulante que alcanza hasta más allá de los omoplatos, y un mechón que forma una alargada voluta y que va a morir por debajo de la oreja, entrando en contacto, en ambos casos, con la barba. Por el lado izquierdo de la imagen, el cabello se divide de igual modo, dejando al descubierto la oreja, muy similar en ambos casos, si bien es preciso dejar constancia de que la oreja del Nazareno es mucho más parecida a la de otros Cristos creados por Fernández, como el de Zaratán (Figura 9) o el conservado en la iglesia leonesa de San Marcelo (Figura 10).

La forma de la barba también es idéntica, como puede apreciarse (Figuras 5, 6 y 7). A ambos lados del rostro, se forman bajo la oreja sendas ondulaciones llameantes que conectan con el final del bigote. Dos largos mechones sobrepasan la barbilla, y forman dos espirales alargadas de un virtuosismo técnico asombroso, todavía un poco más acentuado si cabe en el caso del Nazareno, mientras que un mechón central absolutamente idéntico pone en contacto ambas partes de la barba. El bigote es de nuevo exactamente igual, con una primera sección algo más abultada, que muere junto al labio, $\mathrm{y}$ una segunda que forma dos mechones ondulados que finalizan en contacto con el pelo del carrillo y el de la parte inferior de la barba, con una mínima diferencia, puesto que en el caso del Atado a la Columna, el fino mechón superior se eleva ligeramente (Figura 5).

Existen algunos detalles en la talla del Nazareno que solamente aparecen en las obras de Gregorio Fernández, y especialmente en las de mayor calidad, como las minuciosas laceraciones en la base del cue1lo, al final de la barba, o los pequeños espacios entre el cabello y la piel, mientras que algunos rasgos pueden considerarse como auténticas exhibiciones de maestría y virtuosismo técnico, como el final de la barba y la delicadísima, en todos los sentidos, labor de la gubia en las volutas que forman los extremos de la misma, que resulta un poco más virtuosa si cabe en el Nazareno leonés que en sus gemelos vallisoletanos (Figuras $4,5,6$ y 7).

Resulta difícil cuantificar el grado de similitud existente entre el Nazareno y el Cristo atado a la columna, pero si hubiera que precisarlo, estaría muy cercano al cien por cien. No nos encontramos ante dos imá- 
genes que estén unidas por un wittgensteiniano aire de familia, sino ante dos cabezas gemelas, tanto en sus formas como en la calidad técnica de las mismas.

El Cristo coronado de espinas, revela también estrechísimas similitudes, si bien no en un grado tan extremo como el Cristo atado a la Columna (Figura 3). Las diferencias más importantes se encuentran en el hecho de que la oreja izquierda no resulta visible, que los mechones del final de la barba están ligeramente más juntos, y la parte superior del ojo derecho más hundida. Por lo demás, las tres piezas revelan tales coincidencias formales y estilísticas, sin una sola divergencia, que constituyen suficiente evidencia de que fueron creadas por la misma mano, $y$ en el mismo período creativo.

Las similitudes son aún más extraordinarias si se tiene en cuenta que cada una de las tres imágenes representa un momento distinto de la Pasión. En este sentido, y aunque no es objeto de estudio de este texto, porque abordarlo nos obligaría a rebasar sus límites materiales, resulta fascinante observar cómo Gregorio Fernández reprodujo de un modo sumamente escrupuloso, en la larga serie de pasos procesionales que comenzó a esculpir a partir de 1610, aproximadamente, y especialmente después de 1615, cada una de las afecciones físicas que los diferentes episodios de la Pasión fueron provocando en el rostro y el cuerpo de Cristo. La evolución del reflejo del sufrimiento físico y espiritual en los Cristos de Fernández configura un crescendo que culmina en la postración de los yacentes, y que sólo puede calificarse como sublime.

Por otra parte, la extraordinaria semejanza entre las obras que hemos expuesto no supone un caso aislado dentro de la producción de Gregorio Fernández. En diferentes momentos de su vida creativa realizó versiones virtualmente idénticas de un mismo modelo, con mínimas variaciones. Sin afán de ser exhaustivos, pueden encontrarse ejemplos de este proceder en momentos cronológicos muy distantes entre sí. De este modo, los yacentes de Santa Clara (h. 1606), de San Pablo de Valladolid (h. 1610) y del convento del Sacramento, de Madrid (h. 1611), son sumamente similares entre sí, y especialmente los rostros. En la década de 1630, dos de las obras culminantes de Fernández, el Santísimo Cristo de la Luz, y el Santísimo Cristo de la Agonía, o de los Balderas, ambos realizados hacia 1631, exhiben igualmente unas similitudes extraordinarias (Figura 11). Los yacentes del último período creativo del autor del Cristo atado a la columna presentan asimismo unas características formales intensamente similares. Ello lleva a concluir que, en determinadas ocasiones, y partiendo de algún modelo primario, bien realizado en madera o en cera, Fernández elaboró variaciones apropiadas para los numerosos encargos en los que hubo de trabajar simultáneamente.

La constatación de que la cabeza del Nazareno es objetivamente idéntica a la del Cristo Atado a la Columna, y de que en ella están presentes todos los rasgos técnicos, formales y estilísticos que sólo aparecen en las mejores obras de Gregorio Fernández, permite reivindicar con total nitidez la calidad de la primera, puesta en entredicho en diferentes ocasiones, como hemos apuntado. La cabeza del Nazareno posee exactamente la misma calidad objetiva que pueda atribuírsele a la del Cristo Atado a la Columna, puesto que formalmente es idéntica a ella, lo cual demuestra que los mismos "defectos técnicos en el uso de la gubia" que puedan existir en la cabeza del Nazareno, tendrán también que ser achacados al Cristo atado a la colum$n a$, defectos que, por otro lado, se convierten en asombrosos ejercicios de rigor anatómico, precisión iconográfica y exhibición de maestría técnica después de un análisis minucioso de la imagen (Figuras 1, 5, 6 y 7).

La policromía del Nazareno se ha visto ligeramente afectada en las últimas décadas por intervenciones, tan bien intencionadas como poco afortunadas, que han oscurecido su tez. Aun así, es posible percibir cómo resulta idéntica, tanto en factura como en calidad, a la presente en el Cristo 
atado a la columna. El elemento de la policromía que sí podemos comparar de modo preciso son las gotas de sangre, cuya disposición sobre el rostro es extremadamente similar, en forma y distribución, a las que riegan el rostro del Cristo coronado de espinas. Obviamente, el Cristo atado a la columna no presenta ninguna de dichas marcas, puesto que aún no le ha sido colocada la corona de espinas. De acuerdo con las características espirituales del arte emanado del espíritu y las directrices del Concilio de Trento, todos los rasgos de una imagen religiosa deben estar orientados a lograr una conmoción espiritual en el espectador, que oriente su alma hacia la $\mathrm{fe}^{31}$. En esta búsqueda del impacto religioso a través de la imaginación, tanto interior como exterior, los artistas plásticos alcanzaron un refinamiento lindante con lo morboso, como refleja magistralmente la imitación de la sangre en estas dos imágenes (Figuras 3, 5, 6 y 7). Podemos observar los hilos de sangre más abundantes que brotan del punto de contacto entre la corona y la piel, y cómo los regueros más largos se desplazan a lo largo de la sien derecha, rozando en ambos casos el límite de la ceja. Asimismo, aparecen idénticas gotas de sangre aisladas en la parte baja del pómulo derecho y en la nariz. La parte izquierda también posee una disposición similar de la sangre, aunque presenta alguna diferencia, quizá explicable por ser el lado del que porta la cruz, cuyo roce habría producido alteraciones en su fluir. Esta disposición de la sangre es, de nuevo, no solamente idéntica a la que caracteriza a las obras de Gregorio Fernández, sino que es la misma que estaba presente en la talla antes de las diferentes intervenciones que sufrió a lo largo del siglo $\mathrm{XX}$, como muestran las fotografías. Incluso en el hipotético e improbable caso de que se trate de repintes, estos habrían respetado la distribución preexistente.

${ }^{31}$ Véase E. MÂLE, El arte religioso de la Contrarreforma, Madrid, 2001. S. SEBASTIÁN, Contrarreforma y Barroco, Madrid, 1981. Un acercamiento reciente que presenta varios puntos de interés, en R. PO-CHIA HSIA, El mundo de la renovación católica, Madrid, 2010.
Un aspecto particularmente impresionante, que no resulta perceptible en las fotografías, y que solamente una inspección ocular minuciosa, como la que, gracias a la gentileza de la Cofradía del Dulce Nombre de Jesús Nazareno hemos podido efectuar, es la presencia de sangre en zonas del rostro y del cabello que revelan una obsesión por la verosimilitud naturalista en la representación de los detalles más exquisitamente minuciosos de los efectos de la Pasión. Entre ellos, una serie de numerosas y pequeñísimas laceraciones en el pómulo izquierdo, así como la presencia, en diferentes puntos del cabello, y especialmente en la barba, de gotas y regueros de sangre que resultan prácticamente imperceptibles, pero que sin embargo han sido introducidos por el escultor y por el artista que se ocupara de la policromía como elementos integrantes de la obra. Igualmente impresionantes resultan las gotas que brotan del interior de la oreja, la precisión con la que la sangre bordea con particular intensidad todo el límite del cabello, cambiando sutilmente su tonalidad para sugerir su mezcla con el sudor, y la sangre que ha detenido su fluir, formando voluminosos coágulos en ambos lados del rostro, de un extremado realismo y enorme fuerza expresiva. Particularmente sugerente resulta un hilo de sangre que nace de la parte superior de la frente, bordea el extremo de la ceja derecha, y se desliza hacia el ojo, formando a continuación una lágrima de sangre. Similar disposición se repite en la parte izquierda del rostro, con el añadido de un detalle que resulta especialmente interesante, puesto que se convirtió en una de las características de la obra de Fernández, como es la presencia de sangre y una tumefacción bajo la ceja izquierda. En el Nazareno se aprecia un ancho reguero de sangre en forma de ángulo, que no revela ser continuación de ningún otro, mientras que en las obras posteriores de Fernández la sangre está causada generalmente por una espina que, en los ejemplos más extremos, aparece atravesando violentamente la carne, como en el Cristo de la Luz o el de Zaratán (Figuras 
9 y 11). Igualmente extraordinarios resultan los ojos de cristal, la delicadísima labor pictórica de las formas propias de la superficie del ojo, y la precisa y delicadísima labor de policromía en el trazado de las pestañas.

Todo ello revela no sólo una calidad técnica y artística extraordinarias, sino una atención absolutamente precisa, minuciosa y obsesiva respecto a los más mínimos efectos imaginables del sufrimiento físico, rasgos ambos que sólo aparecen en las obras de Fernández, y cuyos imitadores trataron de reproducir, sin lograr nunca acercarse siquiera a la extremada calidad y escrupulosidad por las que se caracteriza la obra del escultor gallego.

En cuanto a las manos, los diferentes testimonios fotográficos que conservamos, y que no podemos reproducir en su integridad, prueban que no existen diferencias apreciables entre las que actualmente posee y las que muestran las fotografías más antiguas de que disponemos, anteriores a la intervención de Víctor de los Ríos. De nuevo, la extendida creencia de que el escultor cántabro creó unas manos nuevas para el Nazareno se muestra carente de base, puesto que, hasta donde puede apreciarse, la forma es idéntica a la actual, tanto en sus aspectos generales como en los más pequeños detalles.

Por otra parte, las manos del Nazareno son también sumamente similares a las del Cristo atado a la columna, el Cristo coronado de espinas, y el Ecce Homo del Museo Diocesano de Valladolid. La forma de las manos es idéntica, como lo es la disposición de los dedos, más cercanos entre sí el medio y anular en ambos casos, exactamente del mismo modo que en el Ecce Homo y en el Coronado de espinas. Esta característica, por otra parte, no sólo está presente en la mayor parte de las obras de Fernández, sino que puede considerarse otro rasgo distintivo de su estilo (Figura 8). Por otra parte, no guardan similitud con las características formales de las manos esculpidas por Víctor de los Ríos a lo largo de su dilatada trayectoria.
La volumetría de las manos es extraordinariamente rigurosa desde el punto de vista anatómico. El conocimiento de los huesos y músculos de la mano se revela de modo impresionante en las cuatro tallas citadas. La articulación de los dedos es también idéntica. Llama la atención el grado de detalle de cada falange proximal, media y distal, así como de las uñas, que tienen en todos los casos exactamente el mismo perfil. Los nudillos y las marcas de los pliegues de la piel son aspectos igualmente idénticos. Particularmente destacable es el tratamiento de las venas de la mano, cuya exactitud anatómica y detalle sólo encuentra parangón en las del Cristo coronado de espinas y, en menor medida, en las del Ecce Homo. El impresionante tratamiento de la arcada venosa dorsal y de las venas y arterias metacarpianas, y de las digitales palmares, revela un asombroso grado de atención al detalle anatómico pleno de rigor y que, de nuevo, sólo aparece con este nivel de precisión en las obras de Gregorio Fernández. Es extraordinario asimismo el grado de precisión de las arrugas de las articulaciones de cada dedo, más precisos incluso que en sus imágenes hermanas.

El añadido de materiales como cera o betún sobre la policromía original, tan bien intencionados como inapropiados, ha provocado un oscurecimiento de la piel que resalta especialmente todos estos aspectos, pero una observación detenida y comparada prueba que están presentes, de modo menos evidente, en las restantes obras citadas.

Resulta igualmente reseñable la fidelidad anatómica de las palmas de las manos, que incluyen un trazado preciso y precioso de las líneas que la tradición quirológica identificó con las líneas del corazón, la cabeza y la vida. Son muchas las obras de Fernández en las que estas líneas aparecen delineadas con un detallismo extraordinario, como en el caso del Nazareno.

La extraordinaria fidelidad anatómica que comparten las manos de estas obras no sólo constituye una prueba más de que el 
Nazareno fue obra de Gregorio Fernández, sino que permiten constatar, por un lado, los precisos conocimientos de anatomía que el escultor gallego hubo de poseer, y cuya causa más probable quizá quepa encontrar en un vínculo con los estudios propios de la Cátedra de Anatomía Humana, instaurada en Valladolid en 1550. Pero por otro lado, también cabe pensar en una finalidad no sólo "naturalista", sino simbólica y religiosa, puesto que en diferentes pasajes bíblicos se realza la importancia de las manos como formas de manifestación de Dios. Así en la versión de la Vulgata, puede leerse en Job, 37, v.7, "qui in manu omnium hominum signat ut noverint singuli opera sua" (Quien (Dios) sella la mano de todo hombre, para que vean su obra). Por su parte, en Isaías 49, v. 16, se afirma "ecce in manibus meis descripsi te muri tui coram oculis meis semper" (He aquí que en las palmas de mis manos te he grabado, tus murallas están siempre delante de mis ojos).

Abandonando el análisis formal, es preciso aclarar otra objeción que, ocasionalmente, se ha planteado para aducir la imposibilidad de que el Nazareno leonés sea obra de Gregorio Fernández, como sería el hecho de que habría constituido la única ocasión en la que el escultor habría abordado la tipología iconográfica de Jesús Nazareno. No es en absoluto así. En 1614, Gregorio Fernández firma un contrato con la Cofradía de la Pasión de Valladolid para tallar el paso $\mathrm{Ca}$ mino del Calvario. De este grupo escultórico perviven todas las tallas en el Museo Nacional de Escultura, a excepción de la imagen de Jesús Nazareno, que desapareció en una fecha indeterminada. Desde hace años, el paso aparece completo con un Jesús Nazareno caído que erróneamente se ha atribuido a Pedro de la Cuadra. En 1958 el profesor Martín González ya advertía el error. "Se ha insinuado que puede haber sido Pedro de la Cuadra, porque este escultor se comprometía a hacer, en 1623, dos pasos para Grajal de Campos: uno de Cristo a la columna, encarnado a mate, y otro de Cristo con la Cruz a cuestas, para vestir, de manera que se labraría cuidadosamente cabeza, cuello, brazos y manos y parte visible de los pies.
Se conservan ambas esculturas, y a la vista de ellas no es posible pensar en Pedro de la Cuadra como autor del paso vallisoletano, que es mucho mejor" ${ }^{\prime \prime 2}$.

Sin embargo, el modelo de Nazareno que Gregorio Fernández creó en el paso de la Cofradía de la Pasión se puede rastrear en la imagen objeto de este estudio y en las copias que otras localidades cercanas demandaron posteriormente, entre las que cabe reseñar dos, San Cebrián de Campos (Figura 12) y Palencia. Martín González afirma con rotundidad que "el Nazareno que se conserva en la parroquial de San Cebrián de Campos es copia, del último tercio del siglo XVII"33. Jesús Urrea, por su parte, ha precisado que el autor de este Nazareno sería Alonso de Ro$z^{3}{ }^{34}$. En 1694 la Cofradía de Jesús Nazareno de Palencia encarga a José de Rozas, hijo de Alonso, la copia de la imagen principal del citado grupo vallisoletano ${ }^{35}$, grupo que, en palabras de Jesús Urrea, se convertirá en una de sus mejores creaciones ${ }^{36}$. Ambas obras suponen el eco de las imágenes de Jesús con la cruz a cuestas creadas por Gregorio Fernández, cuyo primer ejemplo documentado fue el citado paso, y en cuya serie formal e iconográfica hay sin duda que encajar al Nazareno leonés, así como las citadas obras de de San Cebrián de Campos y Palencia.

En este sentido, cabe pensar que la efigie leonesa pudo ser un encargo realizado a partir del conocimiento de alguna obra tallada por el genio gallego, como el Cristo Atado a la Columna o el propio y lamentablemente desaparecido Nazareno encargado por la Cofradía de la Pasión vallisoletana,

${ }^{32}$ J. J. MARTÍN GONZÁLEZ, Escultura barroca castellana, Madrid, 1958, p. 110.

${ }^{33}$ Ibídem, p. 202.

${ }^{34}$ R. PÉREZ DE CASTRO, "Camino del Calvario", El Árbol de la Vida, Salamanca, 2003, p. 154.

${ }^{35}$ J. J. MARTÍN GONZÁLEZ, "Camino del Calvario. Valladolid. Museo Nacional de Escultura", El escultor Gregorio Fernández, Madrid, 1980, página 203.

${ }^{36}$ J. URREA FERNÁNDEZ, "Paso del Camino del Calvario", Pasos restaurados, Valladolid, 2000, p. 60. 
entre otras. En el hipotético caso de que la cofradía hubiera encargado una copia, es preciso recordar que esta, en el contexto del barroco hispano, no suponía una reproducción exacta tal como permite la técnica del sacado de puntos, sino una imitación de aquella obra que por diferentes motivos interesaba especialmente a una cofradía u otra entidad. Un ejemplo muy evidente es $E l$ Descendimiento que la Cofradía de la Quinta Angustia de Medina de Rioseco encargó a Francisco Díez de Tudanca en 1663 “a imitacion del que tiene la cofradia de la santa bera cruz de esta ciudad de Valladolid que hiço gregorio fernandez" ${ }^{\prime 37}$. Las diferencias de este paso respecto al conjunto tallado por Fernández para Valladolid son evidentes, a pesar de mantener la composición de la escena, y por lo tanto en absoluto puede ser considerado como una copia mecánica.

En cualquier caso, y como ya hemos expuesto, la cabeza del Nazareno no es en absoluto una copia mecánica del Cristo atado a la columna. Existen diferencias de detalle que permiten descartar dicha posibilidad. Asimismo, también puede descartarse por completo que pudiera haber sido realizado por algún miembro de su taller, puesto que en el Nazareno se encuentran incontables muestras de una calidad técnica suprema que solamente se pueden hallar en las mejores obras nacidas de la mano del escultor gallego. Podría incluso llegar a objetarse, en este sentido, que toda esta larga serie de exactas similitudes entre la talla leonesa y las vallisoletanas se debe a que las labores de restauración a las que ha sido sometida la imagen legionense a lo largo del tiempo han acabado por desfigurar su apariencia original y acercarla a los modelos que, como vemos, resultan idénticos a ella. Una simple contemplación de las fotografías anteriores a la intervención de Víctor de los Ríos muestra que, ni en el rostro ni en las manos se produjo modificación alguna, y que el escultor cántabro respetó íntegramente la cabeza

${ }^{37}$ R. PÉREZ DE CASTRO, “El Descendimiento", El Árbol de la Vida, Salamanca, 2003, p. 325. del Nazareno, limitándose a crear un cuerpo y a esculpir, posteriormente, la figura del Cirineo. También resulta inverosímil la posibilidad de que Víctor de los Ríos hubiera creado unas manos absolutamente idénticas a las antiguas, sin haber dejado constancia explícita de ello.

Todo lo expuesto supone una clara evidencia de que el Nazareno, el Cristo atado a la columna, el Cristo coronado de espinas e, incluso, el Ecce Homo, hubieron de ser realizados por la misma mano y en el mismo período de tiempo. Por ello, es preciso intentar precisar con la mayor exactitud posible el marco cronológico en el que pudieron haber sido creadas. Contamos para ello con varios indicios.

El primero de ellos radica en la fecha que tradicionalmente viene siendo asignada para datar la realización del Cristo atado a la columna, 161938. En realidad, se trata de una fecha ante quem, puesto que el documento que certifica la existencia de la imagen corresponde a una solicitud dirigida a Su Santidad con fecha de 22 de julio de 1619. En ella la Cofradía de la Vera Cruz pedía "indulgencia y jubileo a imitación de la llaga que a nuestro Jesucristo le hicieron en sus sagradas espaldas" para quienes veneraran "la insignia y Excehomo de la columna que la dicha Cofradía tiene en el altar de su iglesia" 39. Ello implica necesariamente que la escultura ya había sido realizada con anterioridad, y parece razonable que contara con algunos años de existencia, lo que habría favorecido la formación e intensificación de un culto hacia ella que finalmente habría conducido a dicha petición. Si 1619 es el año ante quem, la imagen fue creada con anterioridad. Sin embargo, no es fácil determinar cuál fue la fecha post quem para su realización. Si nos atenemos a criterios estilísticos, y damos

${ }^{38}$ J. J. Martín González incluye esta imagen en el tercer período de la obra de Gregorio Fernández, comprendido entre 1616 y 1620.

${ }^{39}$ J. J. MARTÍN GONZÁLEZ, “Cristo a la columna. Valladolid. Iglesia penitencial de la Vera Cruz", El escultor Gregorio Fernández, Madrid, 1980, p. 169. 
por válidas las fechas tradicionalmente aceptadas en los principales estudios sobre Gregorio Fernández, es fácil observar cómo la transición desde una estética clasicista y tímidamente naturalista hacia su estilo definitoriamente personal, plenamente riguroso desde el punto de vista anatómico, progresivamente volcado hacia la representación y expresión de los efectos del dolor sobre el cuerpo y el rostro, y sin embargo totalmente equilibrado y moderado, sin la tendencia hacia los extremos lacerantes que caracterizarán su producción posterior, se produce aproximadamente hacia 1615, época de creación del Cristo atado a la columna venerado en el Convento de Santa Teresa de Valladolid (Figura 10a), o la Sexta Angustia, conservada en el Museo Nacional de Escultura de Valladolid, obras en las que aún se aprecian ciertas fluctuaciones estilísticas entre las cualidades formales de sus obras tempranas y las nuevas características que imprimirá a toda su producción. En este sentido, el Nazareno, como el Cristo atado a la columna, resultan también muy cercanos formal y estilísticamente tanto al Cristo de la iglesia de San Pedro Apóstol, de Zaratán (Valladolid) (Figura 9), como al Ecce Homo del Museo Diocesano de Valladolid (Figura 10b), y que, datado en un primer momento hacia $1612-1613^{40}$, es considerado hoy por Jesús Urrea como una obra cercana a 162l, fecha ante quem para su realización, puesto que fue en ese año cuando fue entregada por el clérigo Bernardo de Salcedo a la cofradía del Santísimo Sacramento y Ánimas de Valladolid ${ }^{41}$. De ser correcta esta propuesta, y nosotros consideramos que lo es, habría que situar la creación del Ecce Homo en el mismo período cronológico del Cristo atado a la columna, e incluso puede afirmarse que es muy probable que fuera ejecutado un poco después, puesto que los extremos de

${ }^{40}$ J. J. MARTÍN GONZÁLEZ, “Ecce Homo. Valladolid. Catedral Museo Diocesano y Catedralicio", El escultor Gregorio Fernández, Madrid, 1980, p. 174.

41 J. URREA FERNÁNDEZ, "Ecce Homo, hacia 1621”, Gregorio Fernández 1576-1636, Madrid, 1999, p. 134. virtuosismo técnico que se pueden apreciar en el tallado del cabello, o en el contorno de los ojos, son, si cabe, un poco más acusados y ambiciosos que en las obras de la Vera Cruz o en el Nazareno.

De acuerdo con estos criterios estilísticos y los aspectos históricos que vamos a exponer seguidamente, la horquilla cronológica más adecuada para la realización del Nazareno leonés sería la de los años 16151619. El estudio de la documentación conservada en el Archivo Histórico Provincial de León, así como el hallazgo de documentos inéditos en el mismo archivo, refuerza esta posibilidad.

La Regla de la Cofradía de 1611, en su capítulo decimocuarto, reza: "a lo cual se han de hallar presentes todos los cofrades con su pendón y cruz levantada y un Jesús Nazareno" ${ }^{\prime 2}$. Esta mención a la existencia de un Jesús Nazareno no implica necesariamente que la imagen estuviera realizada en el momento de su promulgación, pero sí que formaba una parte sustancial del proyecto fundacional de la Cofradía leonesa. El capítulo decimoquinto, entre otros, viene a confirmar de forma indirecta que esa advocación e imagen de Jesús Nazareno corresponde a la iconografía de Jesús con la Cruz a cuestas, "pues como dice San Pedro en la Epístola primera, capítulo segundo, para eso padeció y llevó su Cruz a cuestas, para que le sigamos imitando sus pisadas y llevando nuestras cruces si le queremos seguir y caminar en pos de Él" ${ }^{43}$. Seis décadas más tarde, en 1674, la Cofradía encomienda a Francisco Díez de Tudanca, entre otros trabajos, la labor de ahuecamiento de la imagen de Jesús Nazareno: "Y a de aguecar la ymagen de Jesus Naçareno que tiene la compañia y ponerlo lo mas ligero que se pueda y bolberlo a cobrir en la forma que oy esta"44. Ello supone una clara evidencia, por una parte,

\footnotetext{
${ }^{42}$ X. GONZÁLEZ, y L. PASTRANA, La regla de 1611, León, 2003, p. 11.

${ }^{43}$ Ibidem, pp. 11-12.

${ }^{4}$ F. LLAMAZARES RODRÍGUEZ, "El escultor Francisco Diez de Tudanca en la ciudad de León", Tierras de León, 34-35, 1979, p. 56.
} 
de que el Nazareno ahuecado era originalmente macizo, y permite aventurar, aunque sólo sea una mera suposición, que se procedió a efectuar tal operación por el excesivo peso que hubiera podido presentar para ser portado por los hermanos de la Cofradía.

De acuerdo con documentos custodiados en el citado archivo provincial, la actividad de la cofradía de Jesús Nazareno, aunque su regla fuese aprobada en 1611, experimentaría un notable impulso en 1615, por varias razones que de forma sucinta exponemos aquí. En primer lugar, es en 1615 cuando se rubrica la escritura de adquisición y fundación de una capilla en el convento de Santo Domingo con las condiciones acordadas entre la comunidad dominica y la cofradía ${ }^{45}$. Estos trámites se habían iniciado cinco años antes. A lo largo de esta escritura no se menciona en ningún momento imagen alguna ni mucho menos un Jesús Nazareno. Ello permite prácticamente descartar que la imagen existiera con anterioridad, y también que pudiera pertenecer al propio convento, pues de ser así hubiera sido necesario reflejar su existencia a la hora de adquirir la capilla.

Cabe destacar que varios de los cofrades que firman las cláusulas de adquisición de la capilla, en 1615, están ligados al mundo del arte u oficios muy cercanos. "Bentura de Valdes abad presente de la dicha cofradia, Antonio Fernandez platero, Pedro Moro, Pedro Legon, Baltasar Garcia ensanblador, Baltasar García pintor, Francisco Garcia pintor ansimismo que confesamos ser la mayor parte de los cofrades que al presente ay en la dicha compañia"46.

Estos cofrades de Jesús no sólo pertenecen al mundo del arte, y por ello es le-

${ }^{45}$ Archivo Histórico Provincial de León (en adelante AHPL). Fundación de la Capilla de Jhs Nazareno en Santo Domingo de León. Protocolos de Francisco Pantigoso. Año de 1615, Caja 92, nº 130, ff. 337-348.

${ }^{46}$ Ibidem, folio 337 v. Luis Pastrana afirma que Ventura Valdés, era un acomodado zapatero que vivía en la calle Cardiles y que Pedro Legón era cordonero. L. PASTRANA JIMENEZ, "Los estatutos de 1611 en copia de 1848”, La Regla de 1611, León, 2003, p. 3. gítimo atribuirles una intensa sensibilidad artística, sino que, obviamente, estarían bien relacionados y conocerían el panorama artístico del momento. Como consecuencia de su actividad profesional, disfrutarían de una cierta holgura económica, que a la hora de adquirir una imagen les permitiría realizar un encargo a un artista de renombre, o emergente, donde encaja perfectamente la figura de Gregorio Fernández.

Otros documentos atestiguan la buena situación económica de la cofradía durante sus primeros años. Así, el 6 de febrero de 1615 la Compañía del Nombre de Jesús Nazareno escritura un censo por valor de ciento cincuenta ducados. Es decir, la Cofradía entrega ciento cincuenta ducados a Santiago de Tobar y Domingo Beneitez de los que ha de recibir anualmente siete ducados y medio el día de señor San Martino de noviembre $^{47}$. "[...] Sobre todos los quales dichos vienes de tierras y prados y casas con ynformacion de abono que destes ban ynsertos e incorporados nos los dichos santiago de tobar el viejo y maria de Sandoval su mujer y domingo beneytez y maria martinez su mujer fundamos y cargamos los dichos siete ducados y medio de renta y censo en cada un año mientras no lo redimieremos y quitaremos para si enprestamos y sobre todos nuestros vienes muebles e raices avidos y por aber presentes y foturos y esto por raçon de que por compra de ellos recebimos de mano de pedro legon abad que al presente es de la dicha compañia del nombre de jesus nazareno siendo sabidores y presentes Francisco Garcia de aranguiz escribano de la dicha compañia y pedro moro pastelero y antonio ernandez platero seises de la dicha compañia que a ello dieron consentimiento en presencia del presente de que yo el escribano doy fe por si y en nombre de la dicha compañía y cofrades por los quales prestaron caucion de rato grato adjudicatun solbendo ciento y cinquenta ducados que acen cinquenta y seis mil y ziento maravedis en reales de contado plata y quartos y moneda usual y corriente en estos reynos al presente en presencia del presente escribano y

47 AHPL. Protocolos de Pedro López de Vivero. León. Año de 1615, Caja 77, nº 109, ff. 70-84. 
testigo de esta carta del qual recibo y entrega del dinero yo el presente escribano doy fe que paso en mi presencia y los rescivieron los dichos santiago de tobar el viejo y domingo beneytez por si y en nombre de las susodichas mujeres de los quales dichos ciento y cinquentra ducados nos los dichos santiago de tobar el viejo y domingo beneytez nos damos y entregamos por contentos y pagados $[\ldots]^{\prime \prime 4}$. Este hecho demuestra que, en aquel momento, la Cofradía ya contaba con unos recursos económicos considerables con los que bien pudo afrontar la adquisición de una obra de arte de primera magnitud al escultor más prestigioso del momento.

Por otra parte, el 20 de agosto de 1615, la Cofradía firma una escritura de dotación y obligación, documento totalmente inédito hasta el momento, en la que se declara la donación de un retablo a la Compañía del Nombre de Jesús, por parte de Juan Rodríguez de Vivanco, junto con las condiciones que la compañía ha de cumplir en favor del donante y su esposa ${ }^{49}$. Es lógico pensar que el destino de este retablo fuera la capilla de Jesús Nazareno cuyos trámites de adquisición concluyeron aquel mismo año. Un año antes, el día 8 de marzo, la Cofradía decide nombrar una comisión para estudiar el asunto y para determinar la cuantía de la obra:

"baltasar garcia ensanblador y pablo martinez pintor, vezinos de esta ciudad de Leon nonbrados por la Compañia y por su comision de los cofrades de la Compañia del nombre de Jesus, que se sirve y canta en el monesterio de señor santo domingo de esta dicha ciudad para ver lo que vale un retablo que Juan Rodriguez Bibanco lo quiere dar a la dicha compañia con ciertas condiciones que abajo iran descritas digo yo el dicho baltasar garcia bale la hechura de doze figuras de los santos apostoles y Cristo salvador y un Cristo crucificado con san juan y nuestra señora al pie de la cruz y otra figura de nuestra Señora que a de estar en una caxa y una figura de

\footnotetext{
${ }^{48}$ Ibidem, ff. 70-71.

${ }^{49}$ Ibidem, ff. 246-248.
}

un niño Jesus con todos los demas adherentes de ensablaje y talla y alquitetura de el dicho retablo fallo valer toda la dicha madera y hechura de ella ciento y diez ducados. Y yo el dicho Pablo Martínez fallo valer la dicha pintura de todo lo arriba dicho ciento y ochenta ducados. Y esto fallamos ser asi conforme dichos y nuestro arte nos da a entender y lo firmamos de nuestros nombres.

$$
\text { baltasar garcia, pablo martinez" }{ }^{\prime \prime 0} \text {. }
$$

En la relación de las obras no figura ningún Nazareno, lo cual resultaría sorprendente si realmente estuviese ya en poder de la cofradía, dado que su advocación coincidiría con el titullus de la misma, y asimismo con el titullus de la capilla, cuya probada advocación en 1615 demuestra, sin embargo, que estaba consagrada a Jesús Nazareno, y por tanto destinada a albergar una imagen suya, algo que parece corresponderse con las intenciones expuestas en la Regla fundacional, como hemos visto. Ello no permite descartar de modo absoluto, lógicamente, que la imagen no hubiera sido ya encargada en dicho año, pero convierte en mucho más lógica y plausible la posibilidad de que, al menos, no se hallara en propiedad de la cofradía, y por tanto que no hubiera sido tallada todavía, o al menos entregada a la cofradía, en 1615. Es también significativo que en este contrato aparezca detallada la iconografía externa del retablo, sin que se precise la imagen que debería ocupar la hornacina central. Si realmente fue este el retablo de la capilla de Jesús Nazareno, creemos que la ausencia de su mención supone un indicio más de que la imagen destinada a ocupar su lugar principal había sido ya encargada a Gregorio Fernández.

Por otra parte, hay que tener en cuenta que la obra del escultor gallego ya era conocida en la provincia de León en el primer decenio del siglo XVII. En Sahagún realizaría durante estos años una imagen del posteriormente canonizado Juan de Sahagún y

${ }^{50}$ Ibidem, f. 246 r. 
las esculturas del retablo del monasterio de San Benito ${ }^{51}$.

Tampoco hemos de olvidar que pudieron existir vínculos significativos, directos o indirectos, entre el escultor afincado en Valladolid y la Cofradía de Jesús Nazareno de León. El Padre fray Pedro Paladinas, prior del convento de Santa Cruz de Segovia y vicario general de la provincia de España, es quien rubrica la licencia, en 1611, por la cual se permite al convento de Santo Domingo vender la capilla ${ }^{52}$. En aquel momento el citado dominico residía en el convento de San Pablo de Valladolid, lugar donde ya se conocía la obra de Gregorio Fernández, a través de la imagen de un Cristo yacente ${ }^{53}, \mathrm{y}$ donde se producirán futuros contactos con el escultor.

Otra vía de contacto entre la Cofradía y Gregorio Fernández pudo surgir de Diego de Basoco, ensamblador unido por una estrecha amistad con Gregorio Fernández, a quien nombró testamentario. A través del testamento, firmado por Basoco el 16 de noviembre de 1621, sabemos que este ensamblador realizó el retablo de la capilla mayor del convento de Santo Domingo de León ${ }^{54}$.

Todos estos indicios estilísticos, históricos y documentales permiten precisar que el marco cronológico más probable para la realización del Nazareno leonés, sin que pueda descartarse de modo absoluto una ejecución ligeramente anterior o posterior, es el comprendido entre 1615 y 1619. 1615 es, como acabamos de ver, un año decisivo en el devenir de la cofradía, y asimismo un año de transformaciones decisivas en el estilo de Fernández. 1619 es la fecha ante quem,

\footnotetext{
${ }^{51}$ J. URREA FERNÁNDEZ, “Gregorio Fernández en Sahagún de Campos", Tierras de León, no 27, 1977, pp. 41-43.

${ }^{52}$ AHPL. Fundación de la Capilla de Jhs Nazareno en Santo Domingo de León. Op. cit., fol. $345 \mathrm{r}$.

${ }^{53}$ J. J. Martín González data esta imagen hacia 1610.

${ }^{54}$ E. GARCÍA CHICO, "Diego de Basoco", Escultores. Documentos para el estudio del arte en Castilla. Tomo segundo, Valladolid, 1941, pp. 120-121.
}

en cuanto lo es para el Cristo atado a la columna, cuya realización, como hemos mostrado, hubo de ser paralela respecto a la de la imagen del Nazareno.

Por otra parte, y en relación con el problema de la configuración original de la imagen del Nazareno, caben varias posibilidades fundamentales, las cuales han sido planteadas en diferentes ocasiones:

A. Que la imagen fuera tallada de cuerpo entero, dado que fue ahuecada en 1674. En algún momento indeterminado, se separaron la cabeza y las manos del resto, hasta llegar a la configuración actual, resultado de muchos azares históricos y estéticos.

B. Que únicamente se encargara la ejecución de la cabeza al escultor, quizá por ser el conjunto demasiado gravoso, o por algún otro motivo, $\mathrm{y}$ que se configurase con ella una imagen de vestir, a la que más tarde se le añadiría un cuerpo. Se trata de una posibilidad remota, dado que en el catálogo de Gregorio Fernández no existen las imágenes de candelero. Únicamente se pueden encontrar algunas imágenes de vestir, en las que, por cierto, el cuerpo está tallado con pleno rigor anatómico. Entre ellas se encuentran el Arcángel San Gabriel, San Antonio o el Ecce Homo del Museo de Catedralicio, todas ellas en Valladolid. Asimismo, consta que la imagen original fue ahuecada, lo cual exige la existencia previa de un cuerpo macizo. Es cierto que en la producción de Fernández puede encontrarse alguna cabeza tallada de forma independiente al cuerpo, que tallaría otro miembro del taller, como la efigie de San Antonio, perteneciente al convento de Franciscanos de Aranzázu, de la que Martín González añade "preparada para atizonar en el cuerpo, pues se labraría separada del resto, como se hizo usual en la época de mayor colaboración del maestro" ${ }^{\prime \prime 5}$. En cualquier caso, nin-

${ }^{55}$ J. J. MARTíN GONZÁLEZ, "Cabeza de San Antonio. Aránzazu", en El escultor Gregorio Fernández, Madrid, 1980, p. 251. 
guna cofradía encargó a Fernández una imagen de vestir.

C. Que la cofradía contase con una imagen del Nazareno que cumpliera las funciones de culto y procesionales, hasta que pudiera costear la imagen de Gregorio Fernández. Tampoco resulta descabellada, pero la falta de menciones sobre dicha imagen en la documentación existente, invita a descartarla.

La primera de las opciones, a tenor de todo lo expuesto, resulta la más probable, teniendo en cuenta, además, que, como prueba la documentación aportada, la Cofradía se encontraba en condiciones de prestar dinero y, por tanto, también de encargar al escultor más renombrado del momento una talla para la advocación de su titullus.

Todo lo expuesto nos permite plantear formalmente la hipótesis de que la cabeza y las manos de la actual imagen de Nuestro Padre Jesús Nazareno, titular de la Cofradía del Dulce Nombre de Jesús Naza- reno de León, fueron talladas por Gregorio Fernández como parte de un todo escultórico hoy perdido, bien fuera un cuerpo esculpido con pleno rigor anatómico, bien una túnica tallada, entre 1615 y 1619.

En cualquier caso, todas estas consideraciones sólo pueden revestir un carácter hipotético, al menos hasta que algún afortunado hallazgo documental revele de modo más fidedigno cuáles fueron las características originales de una talla cuya atribución al insigne escultor barroco, acertada o errónea, no afecta en absoluto a su objetivamente extraordinaria calidad, increíblemente puesta en duda en alguna ocasión, y revelada sin espacio para la duda por nuestro análisis formal comparativo. Esta constatación de que el Nazareno posee la misma calidad que algunas de las obras maestras de Gregorio Fernández permite revalorizar la consideración de una talla que debe ocupar por derecho propio un lugar destacado en la escultura española del siglo XVII. 


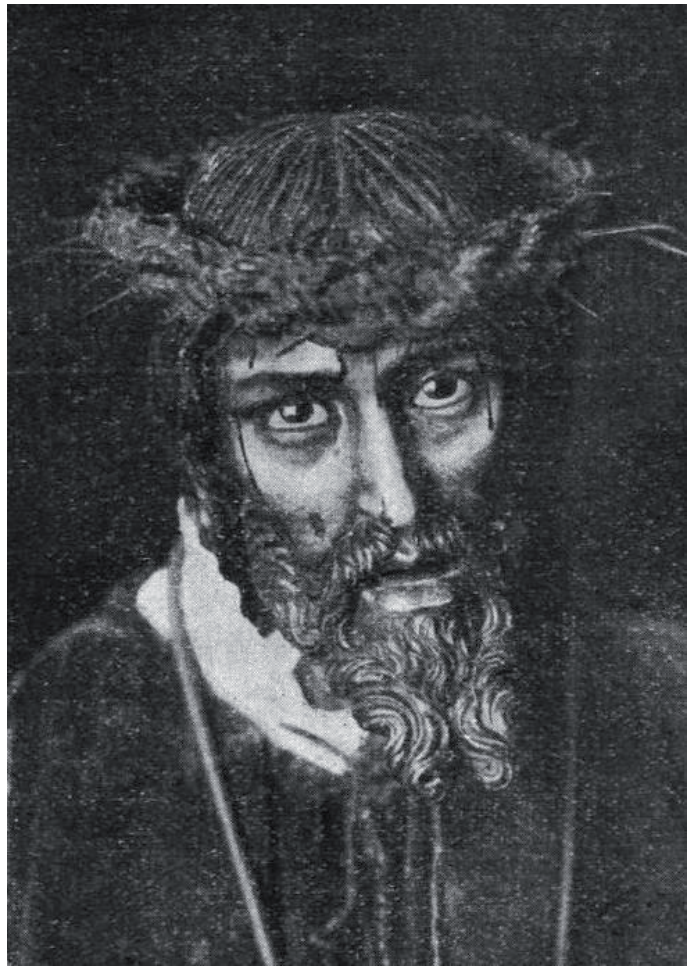

- Fig. 1. Nuestro Padre Jesús Nazareno. Revista Semana Santa, 1928.

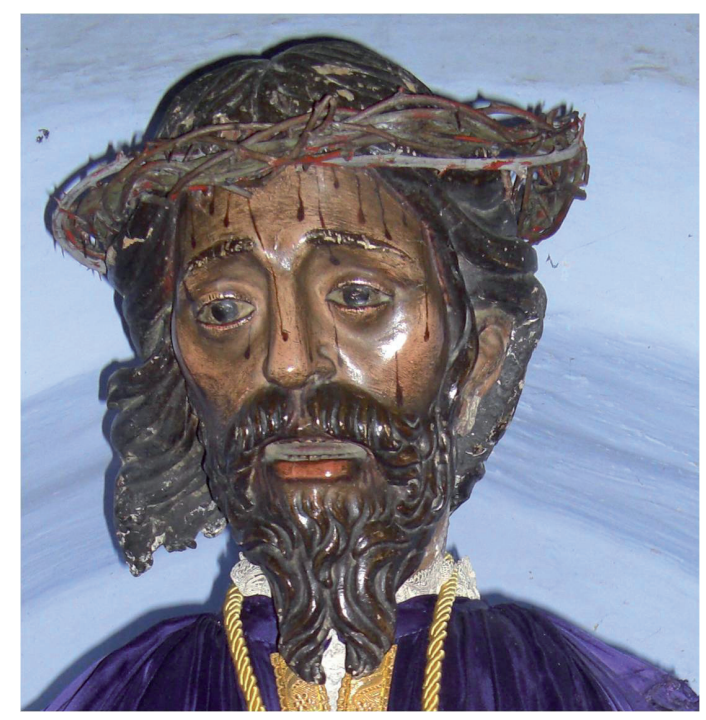

- Fig. 2. Pedro de la Cuadra: Jesús Nazareno. Grajal de Campos. 1623. Fotografía de Eduardo Álvarez Aller.

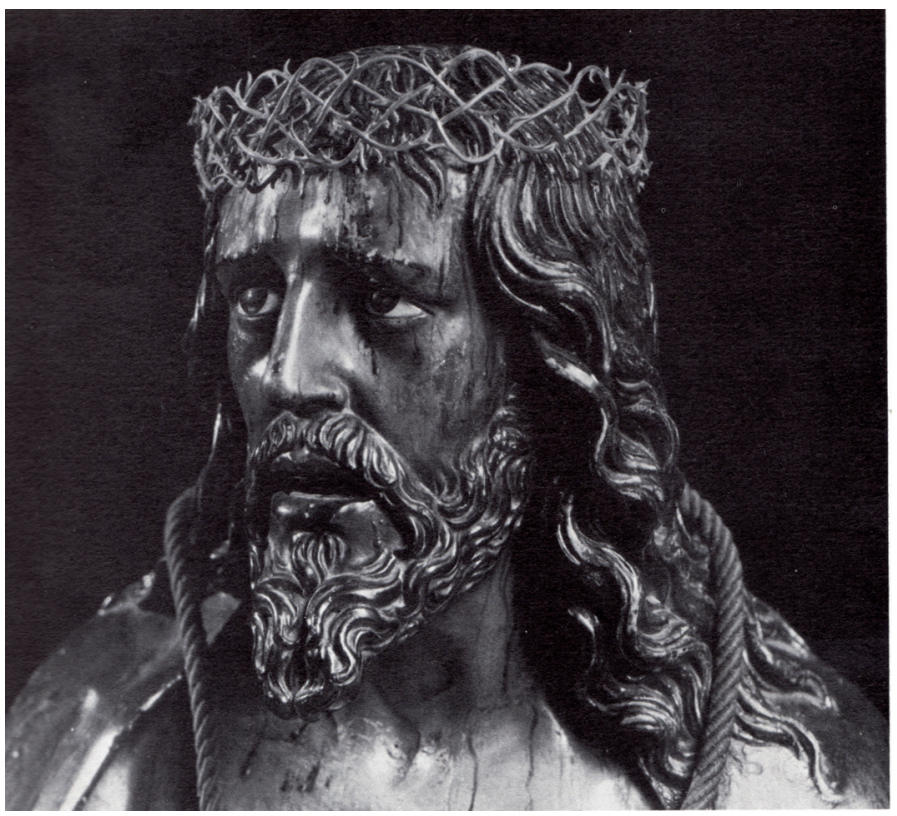

- Fig. 3. Gregorio Fernández: Cristo coronado de espinas. Iglesia de la Santa Vera Cruz, Valladolid. H. 1619. Fotografía anónima. 


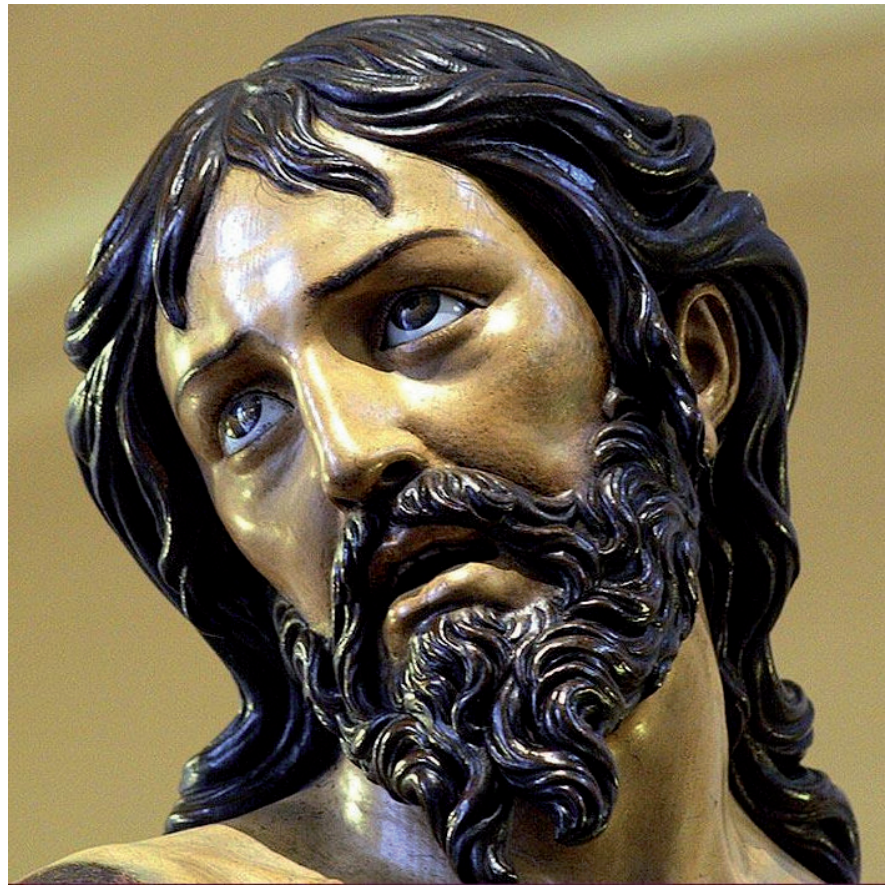

- Fig. 4. Gregorio Fernández: Cristo atado a la columna. Iglesia de la Santa Vera Cruz. Valladolid. (A. 1619). Fotografía extraída del blog Dondepiedad: http://dondepiedad.blogspot.com.es/

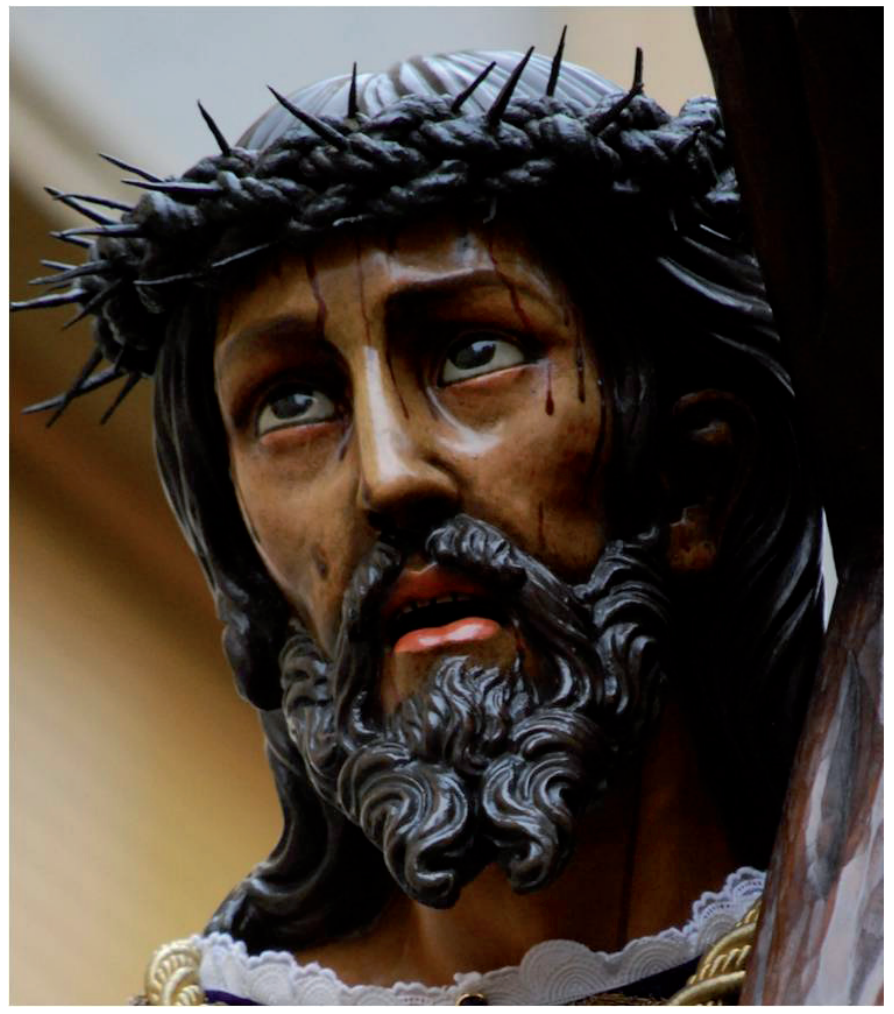

- Fig. 5. Nuestro Padre Jesús Nazareno. Iglesia de Santa Nonia. León. Fotografía de Carlos García Rioja. 

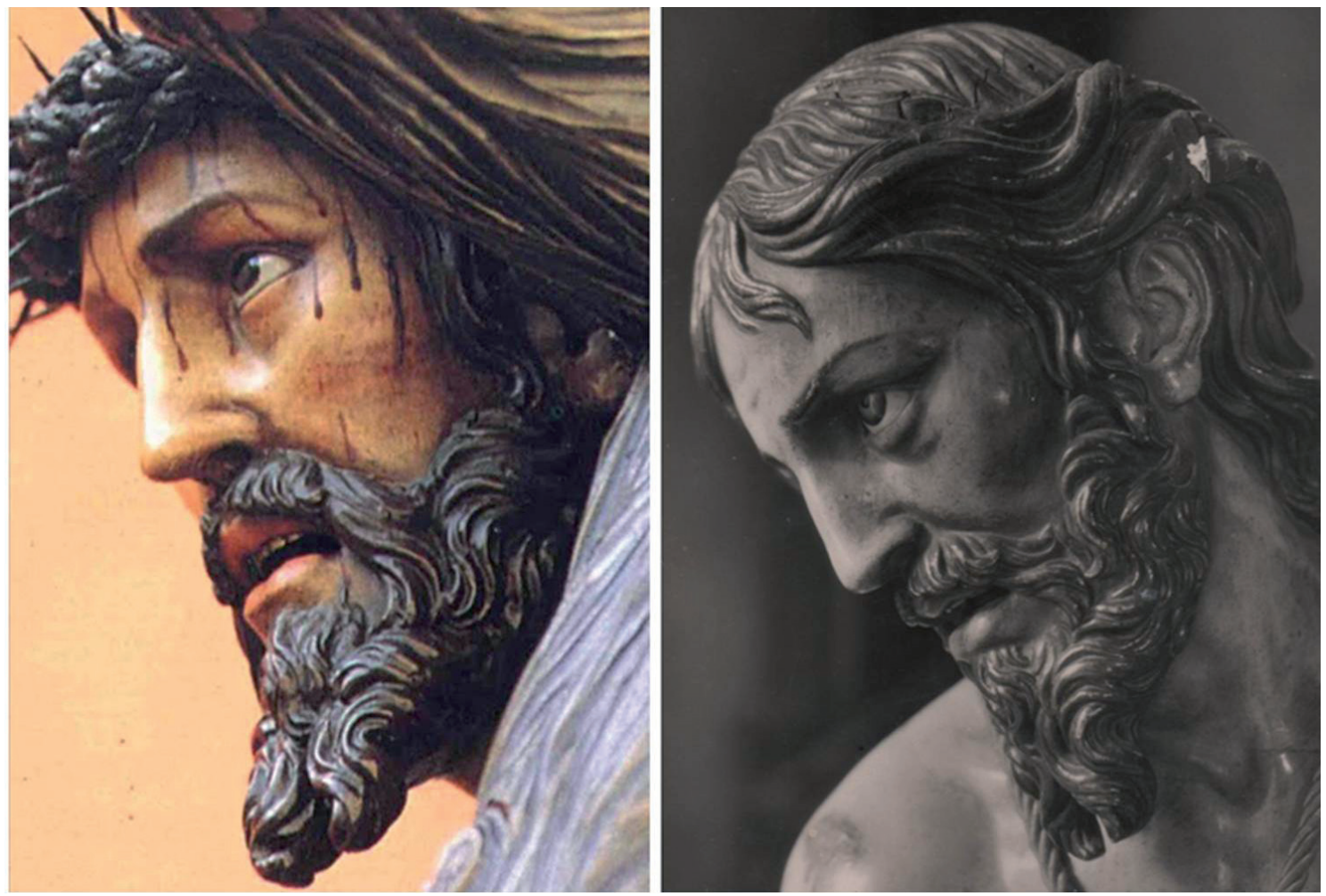

- Fig. 6. Perfil izquierdo del Nazareno (izqda.) y del Cristo atado a la columna (dcha.). Fotografías: anónima y Ediciones García Garrabella.
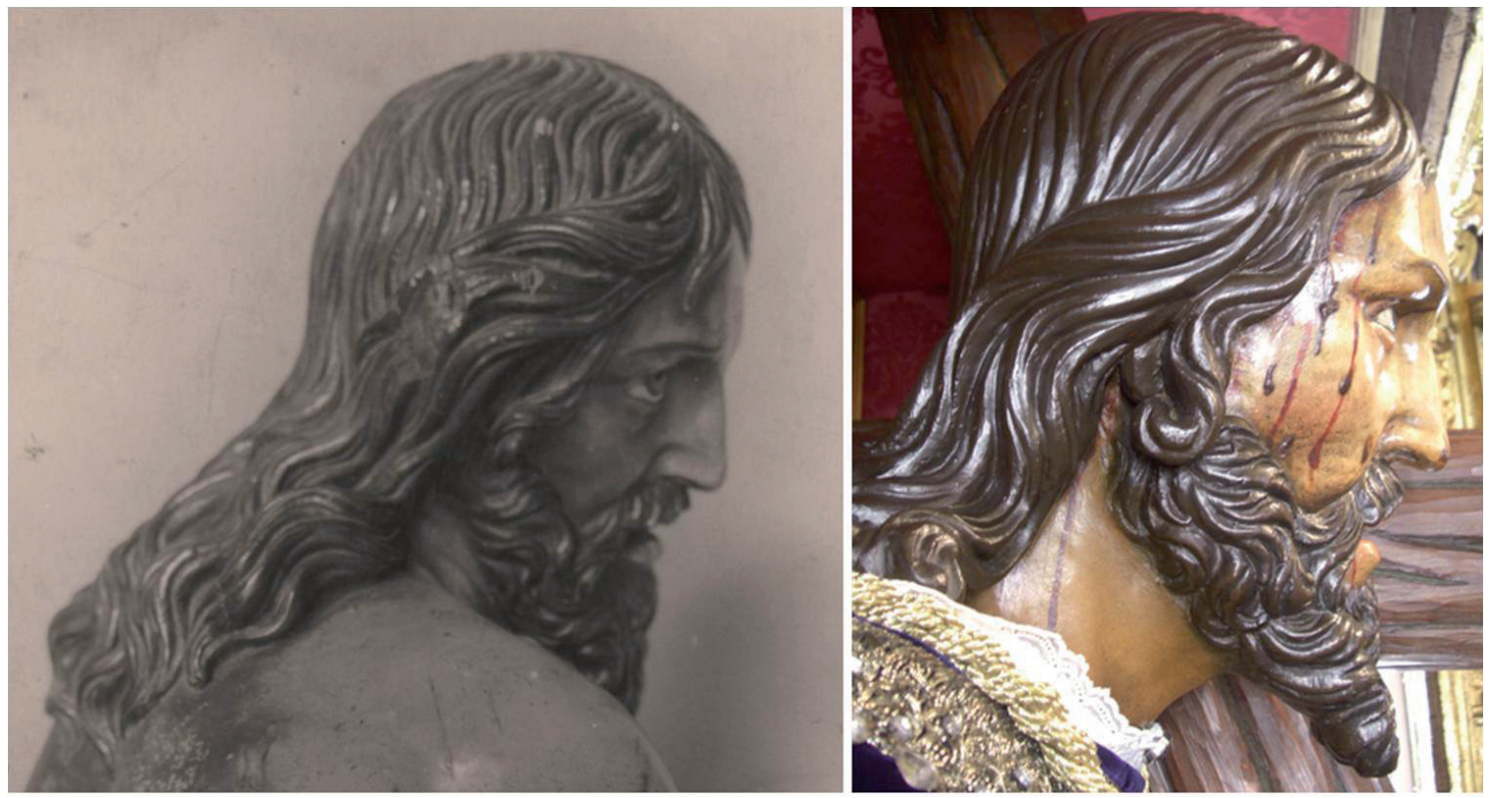

- Fig. 7. Perfil derecho del Cristo atado a la columna (dcha.) y del Nazareno (dcha.). Fotografías: anónima, y de los autores. 

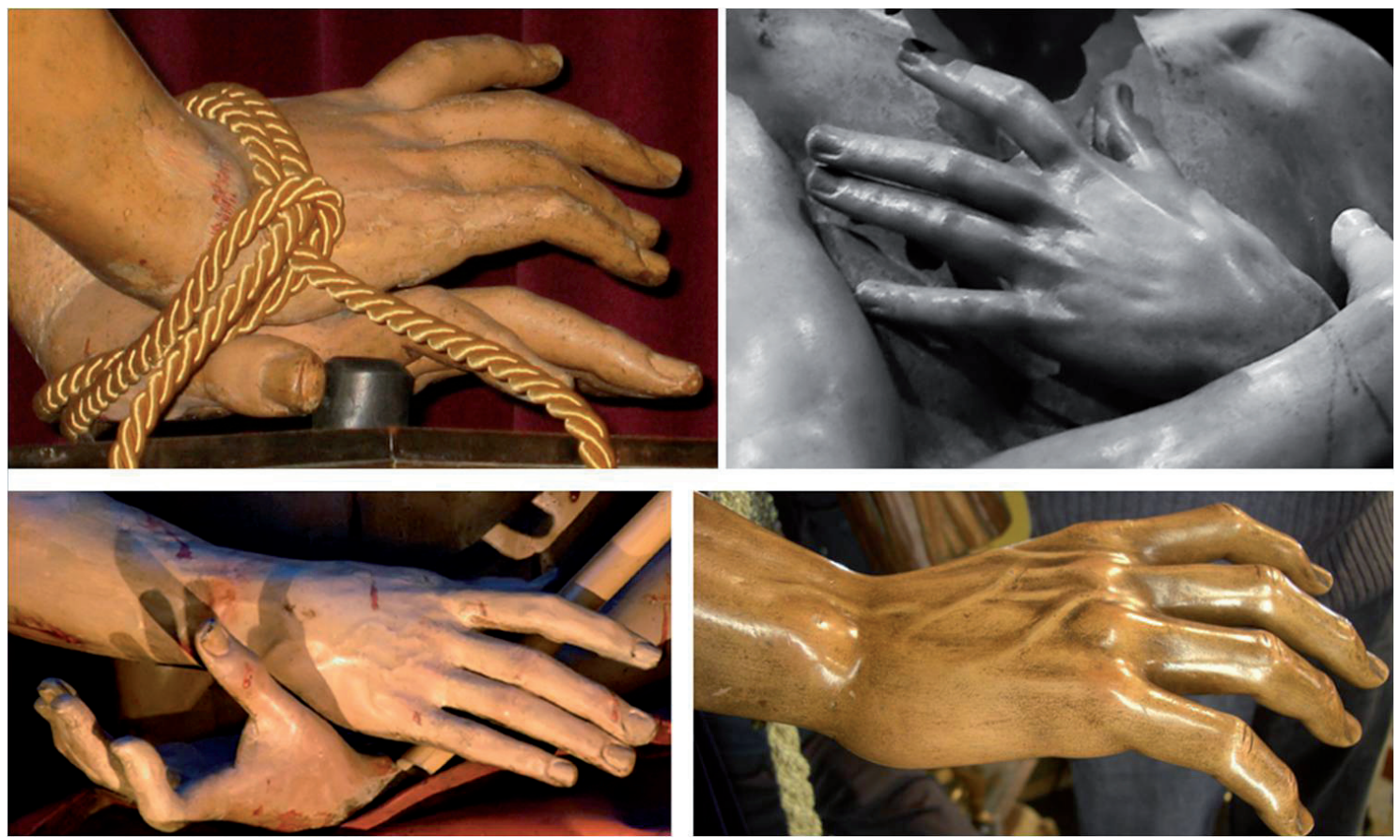

- Fig. 8. De izquierda a derecha. Manos del Cristo atado a la columna, del Ecce Homo, del Cristo coronado de espinas y mano derecha del Nazareno. Fotografías: Dondepiedad, anónima, anónima y de los autores.

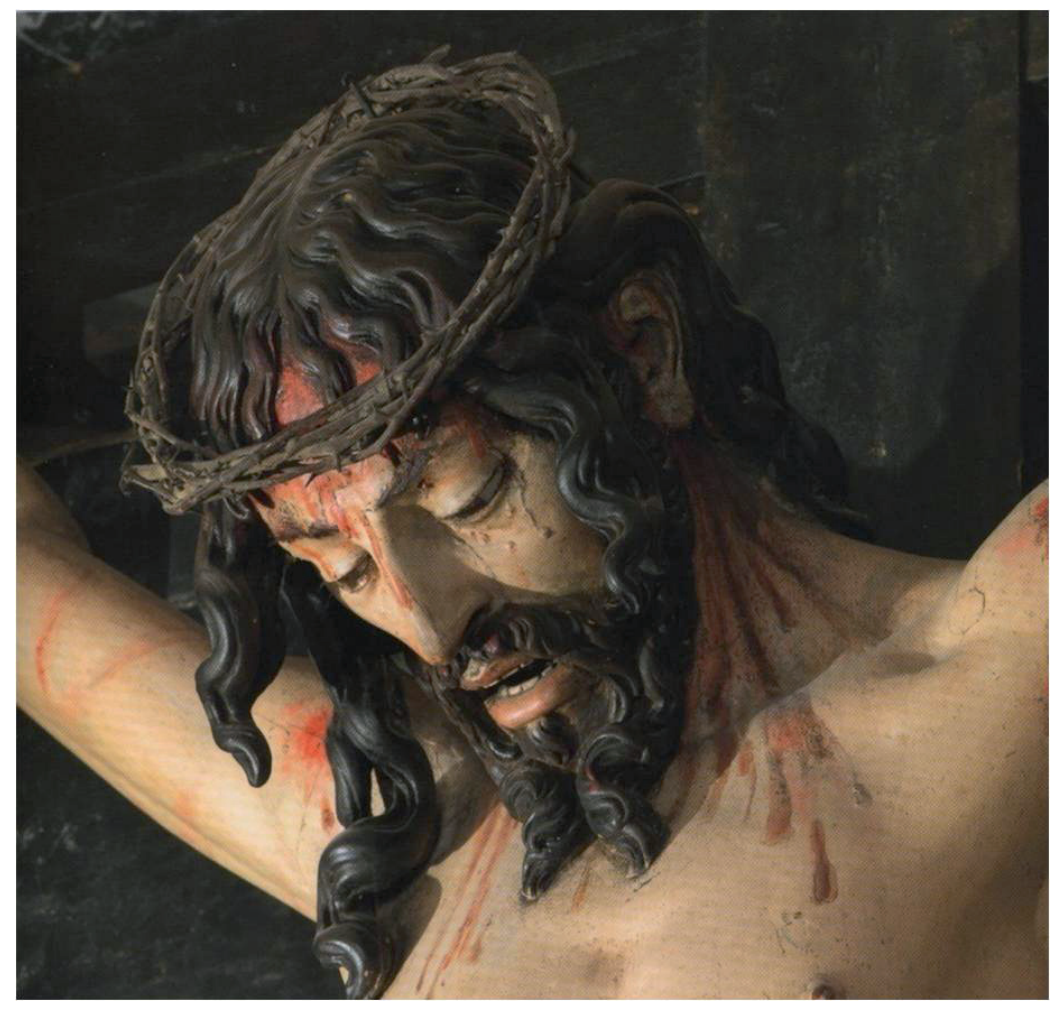

- Fig. 9. Gregorio Fernández: Cristo crucificado. Zaratán. Fotografía del catálogo Passio. Las Edades del Hombre, 2011. 

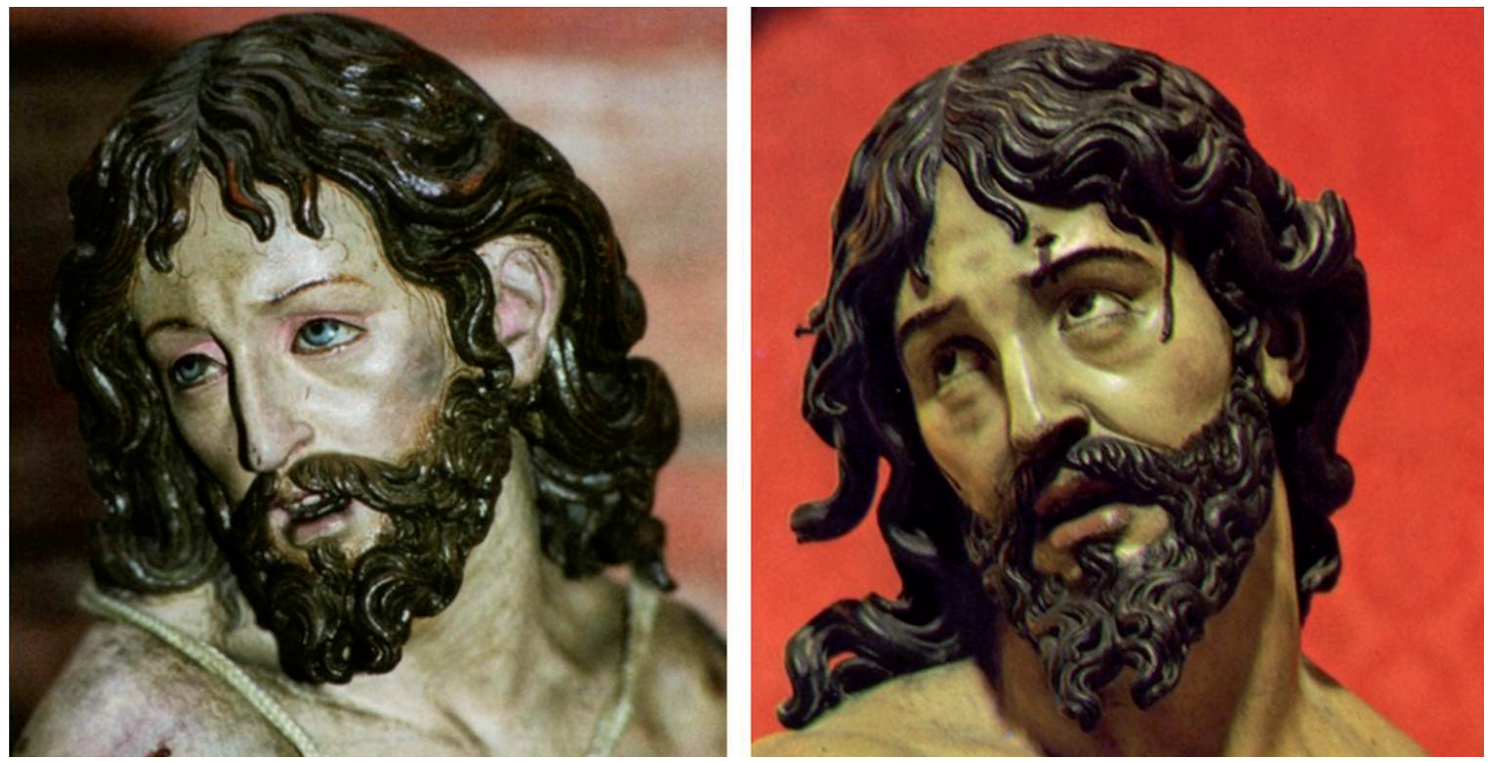

- Fig. 10. Gregorio Fernández. Cristo atado a la columna. Valladolid. H. 1615 (izqda.) y Ecce Homo (dcha.). Museo Diocesano de Valladolid. H. 1620. Fotografías anónimas.
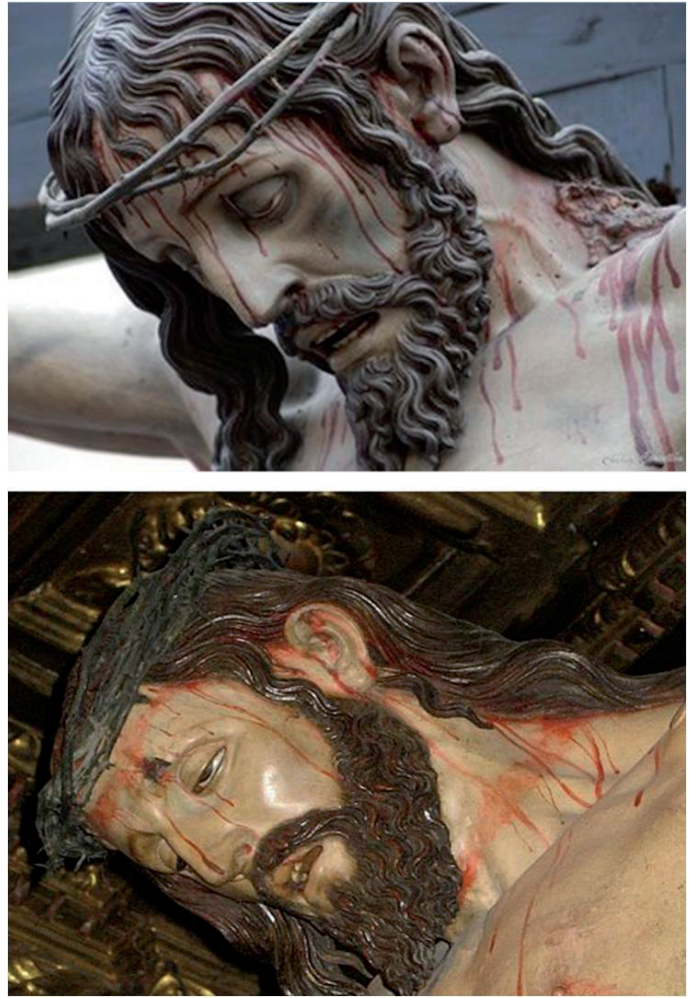

- Fig. 11. Gregorio Fernández: Cristo de la luz. Valladolid. 1631. Cristo de los Balderas. Iglesia de San Marcelo. León. 1631. Fotografías anónimas.

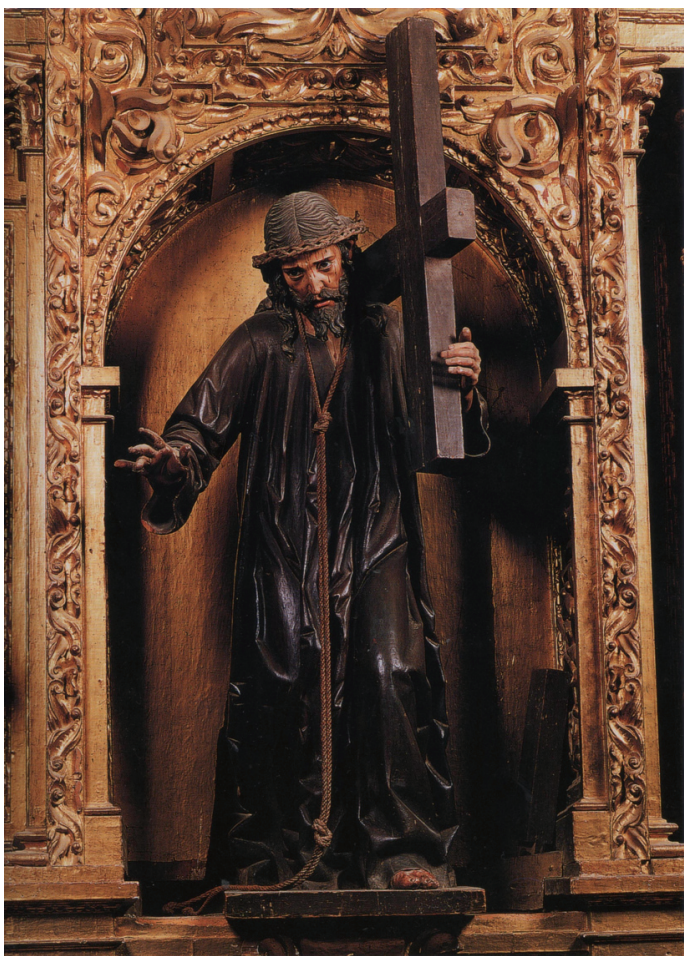

- Fig. 12. Atribuido a José de Rozas. Nazareno. San Cebrián de Campos. Fotografía del catálogo El árbol de la vida. Las Edades del Hombre, 2003. 